\title{
SEASONAL FLUCTUATIONS IN THE SURFACE SALINITY ALONG THE COAST OF THE SOUTHERN PART OF KALIMANTAN (BORNEO).
}

by

Miss SJARMILAH SJARIF.

\section{SUMMARY}

The westerly current of the Java Sea from the southeast is branched to the north, along the eastcoast of Kalimantan (Borneo) as far as Cape Mangkalihat. This current brings high saline water, over $34.0 \%$ ond increases the salinity along the coast of the southern part of Kalimantan, working together with the decreasing rains.

In the westmonsoon, when the westward current has retreated and the easterly current from the South China Sea has developed, the northerly current along the eastcoast is replaced by a southerly current, from ,the Pacific. Under influence of the increasing rains and the large outflow of the rivers in the southern part of Kalimantan the salinity decreases rapidly, until a minimum value. This minimum is found irregularly during the diffferent months of the westmonsoon or the succeeding transition period. The lowest values are found in Sukadana Bay $(29.0 \%$ oo ) and off Bandjarmasin $( \pm 24.0 \%$ о $)$. The further from this place, the higher the values.

The maximum salinity is found during the months September and October in accordance with the minimum rainfall. The highest values are found in the eastern part of the investigated area $(34.5 \%$ oo. To the west it is lower, the more it is mixed with the low-saline water of the Java Sea. The salinity in the Karimata Strait is about 33.0 to $33.5 \%$.

\section{ZUSAMMENFASSUNG.}

Der nach Westen fuhrende Strom der Java See zweigt von Sudosten kommend entlang der Ostkuste Kalimantan (Borneo) nach Norden ab und reicht bis Kap Mangkalihat. Dieser Strom fuhrt stark salzhaltiges Wasser, tiber $34.0 \%$ o und verstarkt den Salzgehalt entlang der Kuste des stidlichen Teils Kalimantans noch mehr, ausserdem durch die sich vermindernden Regenfalle.

Wahrend des Westmonsuns, wo der nach Westen fuhrende Strom zuruckweicht und der nach Osten gehende Strom sich von der Sudchine- 
sischen See ausbreitet, wird der nordlich verlaufende Strom entlang der Ostkuste ersetzt durch einen sudlich fliessenden Strom des Pacific. Unter Einfluss des sich verstarkenden Regens und der grossen Ausstromung des Flusses im sudlichen Teil Kalimantans, nimmt der Salzgehalt bis zu einem Minimum schnell ab. Dieses Minimum wird ersichtlich wahrend der verschiedenen Monate des Westmonsuns, oder der nachfolgenden Ubergangsperiode. Die niedrigsten Werte sind in der Sukadana Bucht $(29.0 \%$ oo $)$ und ausserhalb Bandjarmasins $( \pm 24.0 \%$ oo $)$ zu finden. Je weiter von diesem Platz entfernt, desto hoher werden die Werte.

Der Maximumgehalt ist wahrend der Monate September und Oktober zu verzeichnen, infolge der minimalen Regenfalle. Die hochsten Werte sind im ostlichen Teil gefunden worden (34.5\%). Im Westen werden sie aber niedriger, je mehr sie mit dem wenig salzhaltigen Wasser der Java See vermischt werden. Der Wert in der Karimata Strasse betragt ungefahr $33.0-33.5 \%$.

\section{ICHTISAR.}

Arus kearah barat di Laut Djawa jang berasal dari tenggara bertjabang keutara, mengalir sepandjang pantai timur Kalimantan hingga Tg. Mangkalihat. Arus ini membawa serta air jang berkadar garam tinggi, lebih dari $34.0 \%$ oo dan meninggikan kadar garam disepandjang pantai Kalimantan bagian selatan.

Pada musim barat, djika arus kearah barat berbalik dan arus kearah timur bertambah kekuatannja, arus kearah utara jang mengalir sepandjang pantai timur diganti oleh arus kearah selatan dari Samudera Pasifik. Dibawah pengaruh meningkatnja tjurah hudjan dan banjaknja pengaliran air sungai ${ }^{2}$ di Kalimantan selatan kadar garam dengan tjepat menurun hingga mentjapai minimum. Minimum ini terdapat setjara tidak teratur dalam berbagai bulan selama musim barat atau musim peralihan berikutnja. Harga $^{2}$ minimum jang terendah didjumpai diteluk Sukadana $(29.0 \%$ oo dan dimuka Bandjarmasin $( \pm 24.0 \%$ oo $)$. Semangkin djauh dari tempat ${ }^{2}$ tersebut semangkin tinggilah harga minimum.

Kadar garam maksimum terdapat selama bulan² September dan Oktober bertepatan dengan minimum tjurah hudjan. Harga maksimum jang tertinggi terdapat dibagian timur $(34.5 \%$ oo). Semakin kebarat harga itu semakin turun, karena lebih banjak bertjampur dengan air jang berkadar garam rendah dari Laut Djawa. Kadar garam diselat Karimata kira ${ }^{2} 33.0 \%$ sampai 33.5\%

From former publications it is clear that the pattern of surface salinities in the Indonesian waters is a complex one, influenced by the semi- 
annual changing monsoonwinds as well as by the outflow of the big rivers. This last influence is especially conspicuous in the offings of Sumatra and Kalimantan (Borneo). The big rivers discharging into the seas surrounding these islands have an enormous effect on the surface salinity. During the westmonsoon broad belts of water of low salinity surround these islands. VEEN (1951) already pointed out that to determine the extent to which the surface salinity is influenced by the prevailing monsoon a large amount of data for a number of years is required. Since VEEN (1949) our Institute has continued in collecting surface salinity data.

HARDENBERG and SOERIAATMADJA (1953) have shown the importance of the fluctuations in the surface salinity in connection with the lajang (Decapterus spec.) fisheries in the western part of the Java Sea. According to the Biological Division of the Seafisheries Service at Djakarta, one of the most important fishes off the coast of the southern part of Kalimantan is the kembung (Rastrelliger spec.). Two species are found, i.e. Rastrelliger kanagurta mainly along the southeast coast and Rastrelliger neglectus at the westcoast (Sukadana Bay) during October - April. The optimum salinity for R. kanagurta is about $31.0 \%$ oo to $33.0 \%$ o and for R. negletus somewhat lower. In how much the appearance and disappearance of Rastrelliger is influenced by the changing salinity is still to be investigated. We hope that this paper will contribute to practical fisheries.

This paper is based on all the data available at our Institute, which were assembled by Captain K. M. VAN WEEL in 1917 and 1918, a few scattered data from Snellius and Dana (1929 -1930); from 1937 onwards the Institute for Marine Research at Djakarta collected data in the Java Sea, from Sunda Strait to the southern part of Macassar Strait. These activities were stopped in December 1941 at the outbreak of war. In 1949 VEEN, then Oceanographer of the Marine Institute at Djakarta, started an extensive survey of surface salinities over the whole area of the Indonesian Archipelago. This survey was made possible through the courtesy and voluntary co-operation of all Captains and Officers of private navigation companies, the government Navigation Service and Lighthouse-keepers. The procedure of collecting and analysing watersamples has been described extensively by VEEN (1951 and 1953) and SOERIAATMADJA (1956).

The area surveyed (Fig. 1) includes the region between $1^{\circ} \mathrm{S}$ and $5^{\circ} \mathrm{S}$, extending from the South China Sea $108^{\circ} \mathrm{E}$ to the Strait of Macassar $118^{\circ} \mathrm{E}$, occupying the southeastern outlets of the South China Sea, the whole northern part of the Java Sea and the southwestern outlets of the Macassar Strait. This area is very much influenced by the large drainage of the big rivers in the Southern part of Kalimantan. It belongs to the Sundaflat and 
is a very shallow sea with a gradual slope from the coast to the centre, with a maximum depth of about 50 meters, except at several places of the far eastern end at the border of the Sundaflat, where greater depths occur.

The number of available data amounts to 16.768 up to December 1958 . The area surveyed is divided into 28 one-degree squares, although the frequency of observation data is not the same (tb. 1 and 2). Some squares contain more than 1000 observations, and others less than 100 (S. 0315 only 12 and therefore no analysis is made for this area). The mean surface salinity value for each square is derived from the monthly means of each year.

From fig. 2 and 3, which represent isopleths of the surface salinities in the northern part of the Java Sea, we may see, that the annual range in the eastern part is larger than in the western part. This phenomenon was also noted by SOERIAATMADJA (1956) for the southern part. Only in the latter the lowest value for the West monsoon is found in the western part, being higher eastwards. This is not the case in the northern part. The minimum salinity decreases towards $115^{\circ} \mathrm{E}$ and afterwards increases again. In the western part the annual range is from $31.5 \%$ oo) to $33.1 \%$ o at $115^{\circ} \mathrm{E}$ from $29.5 \%$ oo to $34,1 \%$ and in the most eastern part from $31.0 \%$ to $34.5 \%$ oo. According to BERLAGE, VEEN and SOERIAATMADJA, the Java sea is influenced by two different monsoon currents in concordance with the seasons. One from the east with high salinity and another from the west with low salinity. The low salinity in the west monsoon is not only caused by the eastward current from the South China Sea, but also by the large drainage of the big rivers in the southern part of Kalimantan. The influence of these rivers is very conspicuous in the northern part, compared with the southern part of the Java Sea, especially off Bandjarmasin, where the salinity can drop below $24 \%$. This low salinity can still be noted farther south in square S. 0514.

According to the Eastern Archipelago Pilot (1949) the horizontal movement of the water along the south coast of Kalimantan is a mixture of tidal streams and monsoon currents. In the northwest monsoon a predominating eastgoing stream may be expected, and in the southeast monsoon a westgoing stream. That these monsoon currents and tidal streams influence the salinity, has been described above.

In the Macassar Strait a southerly or south-south-westerly current is generally observed in the open part throughout the year. But in the great bight southward of Cape Mangkalihat it is stated that there is a constant northerly current along the Kalimantan coast; just outside this current the general southgoing current may sometimes be running at a consider- 
able rate. During the southeast monsoon, from April to October, the current runs northward along the whole of the eastcoast of Kalimantan as far as Cape Mangkalihat, where it turns southeastward and southward to join the general southgoing current. This current is probably caused by the westgoing monsoon current of the Java sea, striking the east coast of Kalimantan and thus tending to pile up the water on the western side of Macassar Strait. In the northwest monsoon the northerly coastal current is not present. In the southern part of the Macassar Strait the direction of the southgoing current is influenced by the prevailing monsoon. In June - September it is southwesterly, and so on emergence passes into the westgoing current of the Java sea. In November - March it becomes southeasterly and so passes into the eastgoing current of the Java and Flores Sea.

\section{A. The transition period March - April - May.}

During this monsoon-change, along the southcoast of Kalimantan, between $3^{\circ} \mathrm{S}$ and $4^{\circ} \mathrm{S}$. and $108^{\circ} \mathrm{E}-118^{\circ} \mathrm{E}$ a sharp decline in salinity occurs from west to east, which is caused by the eastgoing current from the South China Sea, and the salinity decreases the more it is mixed with river water $\& i$ the southern part of Kalimantan. Between $108^{\circ} \mathrm{E}$ and $110^{\circ} \mathrm{E}$, which comprises open sea and is a part of Karimata Strait, the salinity is about $31.5 \%-32.5 \%$ - From $110^{\circ} \mathrm{E}$ to $115^{\circ} \mathrm{E}$., the area with low salinity approaches the coast more and more. In the Bay off Bandjarmasin the salinity is the lowest, but here a pronounced increase in salinity caused by the beginning westerly current in the period March - May already occurs (fig. 4a), while in other places the salinity is about the same and has an increase or decrease of $1 \%$ maximum. The salinity $(30.0 \%$ o $31.5 \%$ oo $)$ in the Strait of Macassar is lower than in Karimata Strait. In June the westerly current spreads further westward and the salinity increases up to $111^{\circ} \mathrm{E}$.

South of this area, from $4^{\circ} \mathrm{S}$ to $5^{\circ} \mathrm{S}$. (fig. 5a) between $108^{\circ} \mathrm{E}$ and $115^{\circ} \mathrm{E}$., there is also a decline to the east, but not so sharp. More eastward the salinity increases again. West of $113^{\circ} \mathrm{E}$ the salinity range is only about $1 / 2 \%$ о $>$ while to the east the salinity increases clearly, although in the most eastern part $(31.0 \%-31,5 \%$ oo $)$ it is still lower than in the western part $(31.7 \%$ oo $-32.2 \%$ oо $)$

At the westcoast from $1^{\circ} \mathrm{S}$ to $5^{\circ} \mathrm{S}$ the salinity increases from Sukadana Bay southward, the further it is from the coast. Except in Sukadana Bay $(30.0 \%-31.5 \%$ oo $)$ the salinity in the westcoast has only a range of $1 / 2 \%$ maximum, varying from $31.5 \%-32.0 \%$ or $32.0 \%-32.5 \%$ o during these months (fig. 6a). 
On the eastcoast, from $1^{\circ} \mathrm{S}$ to $5^{\circ} \mathrm{S}$., the salinity decreases from north to south (fig. 7a), in accordance with the southward current. This current gradually mixing with coastal water, becomes less saline. In May the current along the east coast of Kalimantan turns to the north and meets the southerly current in S. 0216. In June there is already a reverse course of the salinity, being higher in the south than in the north. Here the salinity range is much higher than in the westcoast.

\section{B. The full eastmonsoon June - July - August.}

The horizontal differences in salinity become lesser and there is a distinct increase from month to month, up to September. The westerly current has fully developed, and now we have a reverse condition, the salinity being higher in the east than in the west, with the lowest concentration moved to the west. In September it is found in the area S. 0312. This is due to the strong current with high saline water from the southeast, which pushes the low saline water off Bandjarmasin to the west. The horizontal difference is not only caused by the monsoon current, but also by the river drainage. This is evident in September, when the outflow of the rivers is much less, and the lowest concentration in the middle drops only $1 \%$ oo (fig. $4 b)$.

Like the northern area, in the south there is also a distinct increase up to September, caused by the westward current and the lesser rain. That lesser rains effect the salinity is clearly illustrated in the disappearing of the lowest concentration at square S. 0414. The westerly current looses its high concentration when it spreads to the west, the more it is mixed with the low saline water of the Java Sea. Under influence of this current the salinity in the east is higher than in the west. (fig. 5b).

In June and July the salinity at the westcoast is about the same, slightly lower than in the monsoonchange (between $31.0 \%$ on and $32.0 \%$ oo), and gradually decreasing from the south to Sukadana Bay. (fig. 6b). In August the salinity increases in the whole area, up to September, except in Sukadana Bay, where it drops at the start of the rains.

The northerly current along the eastcoast of Kalimantan, as is indicated by the Eastern Archipelago Pilot, now fully developed, can be seen clearly in the decrease from south to north. This current with high salinity as a branch of the westerly current of the Java Sea originates from the Flores Sea, is piled up on the western side of Macassar Strait and flows to the north, loosing its high saline character the more it is mixed with coastal water. That the salinity off Balikpapan is slightly higher than south of 
it, is assumed to be caused by the mixture of higher saline water from the south-south-westerly current, (fig. 7b).

\section{The transition period September - October - November.}

With the beginning rains and the retreat of the westerly current, the water becomes less saline, the lowest concentration moves back to S. 0314, and the decline in salinity to this area becomes steeper. The salinity still decreases until December (fig. 4c).

The highest salinity is generally found in the month September, when the westward current reaches its maximum advance, and the rainfall its minimum, except in the squares S. 0412 to S. 0415, where higher salinities are found in October. In November the salinity decreases clearly, and in December the great outflow of rivers off Bandjarmasin is shown again in the lower salinity particularly at S. 0414. (fig. 5c).

The picture in the west coast is nearly the same as in the dry season, only the decrease towards the coast is steeper, and the salinity drops a little from month to month, more pronouced in the south due to the retreating westerly current (fig. 6c).

In September and October the salinity along the southeast coast has its highest concentration. The northerly current reaches its maximum advance and starts to retreat. The southerly current sets in. The salinity decreases in the whole area by the increasing rains, and in December there is a reverse condition, the salinity being higher in the north than in the south. At S. 0416 the influence of the retreating northerly current is still felt, the salinity being slightly higher than in S. 0316 (fig. 7c).

\section{The full westmonsoon December - January - February.}

During the wet season there is no definite decrease in salinity from month to month, except in the eastern part, where the salinity decreases until February and in S. 0314 until March. For the lowest concentration, no regularity could be found in the different months of the westmonsoon or the following transition period (fig. 4d). This is also clear from the sinusoides (fig. 9). In February when the eastward current has fully developed the salinity in the east is lower than in the west, and the decline towards S. 0314 is very steep.

South of this area the salinity decreases slightly in the western part, the lowest salinity being found in March. In the east, like in the case above, the decrease is more distinct with a minimum in February. Here also the salinity in the months January and February is higher in the west than in the east (fig. 5d). 
That the westerly current has retreated and the easterly one influences the region, is also clear from the decrease in salinity from S. 0209 - S. 0409, whereby Sukadana Bay contents coastal water with lower concentration (fig. 6d). The seasonal fluctuations in the southwest is not great, which also can be seen from the sinusoides (fig. 8, 9 and 10). It is a characteristic of the whole South China Sea. The mean annual salinity of the Java Sea, south of Sukadana Bay is higher, e.g. from Sukadana Bay southward 30,7\% $32.1 \%$, $32.3 \%$ and $32.2 \%$.

Now the southerly current is fully developed. The more southern, the lower the salinity. That the area of S. 0416 has a much lower concentration, although it is a part of the open sea, is also explained by the low saline water of the eastward current (fig. 7d). On the whole, the salinity in this region is decreasing from month to month until January by the increasing rains and the outflow of rivers. Compared with the westcoast the annual range in the eastcoast is higher, about $3.5 \%$ oo to $4.5 \%$ ond in the west about $1.5 \%$ oo to $2.0 \%$ caused by the high saline water of the South Pacific, which flows straight into the Macassar Strait. The situation of the annual means of salinity is reversed, showing a decrease from north (Balik-papan) to south, i.e. 32.4\%; $32.1 \% ; 32.0 \%$ ond $32.0 \%$ oo

Fig. 8, 9 and 10 illustrate the annual variation in the salinity of every square, while the dotted lines show the annual means. In all parts along the coast of the southern part of Kalimantan there is a decrease of the annual means from the sea towards the coast.

Compared with the southern part of the Java Sea (SOERIAATMADJA 1956), there is no gradual increase in the annual means from west to east in the northern part, because here the influence of riverwater is much stronger. The annual means between $3^{\circ} \mathrm{S}$ and $4^{\circ} \mathrm{S}$ shows a decrease running from west to $115^{\circ} \mathrm{E}$.. which is, as mentioned above, caused by the outflow of rivers. Nearer to the east the annual means increase again (fig. 9). Between $4^{\circ} \mathrm{S}$ and $5^{\circ} \mathrm{S}$. there is indeed a slight increase to the east, but from $112^{\circ} \mathrm{E}$. to $115^{\circ} \mathrm{E}$. it decreases clearly, to increase again afterwards (fig. 10).

Like in the southern part the increase in salinity in the eastern section starts in the period March - May, when the eastgoing current gradually decreases and finally is replaced by a reverse current, which means an invasion of the oceanwater into the Java Sea. This waterbody with high salinity over $34.0 \%$ oo reaches its maximum advance at the end of the succeeding full eastmonsoon (September) at $113^{\circ} \mathrm{E}$. between $4^{\circ} \mathrm{S}$ and $5^{\circ} \mathrm{S}$., which is more to the east than in the area between $5^{\circ} \mathrm{S}$ and $6^{\circ} \mathrm{S}\left[112^{\circ} \mathrm{E}\right]$, and does not reach the area between $3^{\circ} \mathrm{S}$ and $4^{\circ} \mathrm{S}$.. The advance of this ocean water is 
in accordance with the salinity chart by VEEN (1953), but too far to the west if compared with WYRTKY'S September salinity chart, which is only composed of data of one year (1955).

The highest salinity, like said before, is found in all cases in the month September. Only in some squares, the salinity in the month October is as high. The gradual displacement of the highest concentration from September in the eastern section to November in the western section in the southern part of the Java Sea is not found here. And the sudden drop in salinity in December, found in the southern part, is found in November in the northern part.

As previously stated, besides the influence of the monsooncurrents, the influence of precipitation is important. Therefore several diagrams (fig. 11 and 12) about the annual variation in rainfall in the coastal area of the southern part of Kalimantan are presented, derived from BERLAGE'S and more recent data, which were kindly placed at our disposal by the Meteorological Institute at Djakarta. Although this was worked out only for 9 squares, a strong correlation between yearly salinity variation and rainfall is observed. This correlation, however, is not found between the absolute values. From June to December, during the full eastmonsoon and the succeeding monsoonchange, there is a distinct decrease in rainfall to a minimum in September - October and afterwards an increase to December, with the reverse condition regarding the surface salinity, except in square S. 0109, where the minimum rainfall and maximum salinity are found in July -August. In the wet season and the next monsoonchange there is not such a strong correlation between the maximum rainfall and minimum salinity in the same month. The fluctuations in this period are irregular, both as to rainfall and salinity, although there is some correlation, e.g. the maximum rainfall is found in December and March (S. 0311), in May (S. 0312) or in January and March (S. 0116) and the according minimum salinities in January and April, in May, and in February and April.

\section{ACKNOWLEDGEMENTS.}

Acknowledgement is given to the Officers of the several private navigation companies and to Officers of the government Navigation Services, who operate regularly along the coast of the southern part of Kalimantan (Borneo), for their voluntary cooperation in taking water samples.

Sincerest thanks are extended to Mr. R. E. SoERIAATMADJA, Head of the Lembaga Penjelidikan Laut at Djakarta, and Dr. A. KostermAns for their criticism and suggestions in preparing this paper and to the the Meteorological Institute at Djakarta for the rainfall data. 


\section{REFERENCES.}

Berlage, Jr. H. P., 1927. Monsooncurrents in the Java Sea and its entrances. Konin-klijke Magnetisch en Meteorologisch Observatorium te Batavia. Verhande-lingen 19.

, 1949. Regenval in Indonesie (Rainfall in Indonesia). Koninklijke Magnetisch en Meteorologisch Observatorium te Batavia. Verhandelingen 37.

British Admiralty, 1949. Eastern Archipelago Pilot Vol. II Chap. XII - XIII Hydro-graphic Department, Admiralty London.

HardenBerG, J. D. F. and SoeriaAtmadja, Rd. E., 1956. Monthly mean salinities in the Indonesian Archipelago and adjacent waters for the months March 1950 -February 1953. Organization for Scientific Research in Indonesia. Bulletin 21.

SOERIAATMADJA, Rd. E., 1956. Seasonal fluctuations in the surface salinity off the North coast of Java. Penjelidikan Laut di Indonesia (Marine Research in Indonesia) 1.

VEEN, P. CH., 1951. Surface salinities in the Indonesian Archipelago and adjacent waters. Organization for Scientific Research in Indonesia. Publ. 33.

, 1953. Preliminary charts of the mean salinity of the Indonesian Archipelago and adjacent waters. Organization for Scientific Research in Indonesia, Bulletin 17.

WYRTKI, K., 1955. Surface salinities in Indonesian and surrounding waters January 1955 - September 1955. Lembaga Penjelidikan Laut (Laboratory of Marine Research) Indonesia.

, 1956. Monthly charts of surface salinity in Indonesian and surrounding waters. Journal du Conseil pour l'exploration de la Mer. 3.

1956. The Rainfall over the Indonesian Waters. Kementerian Perhubungan Lembaga Meteorologi dan Geofisik. Verhandelingen 49. Djakarta, Indonesia. 


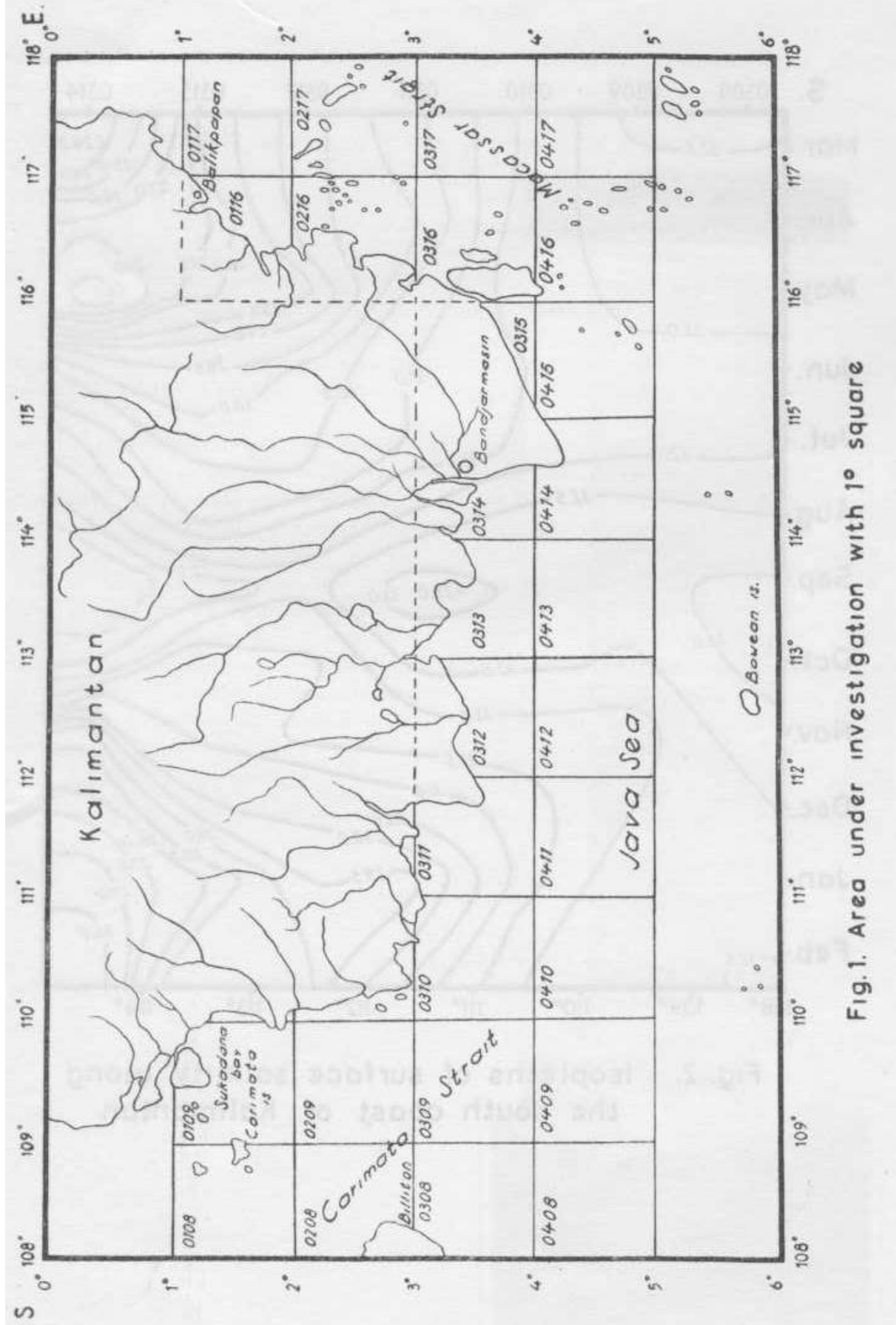




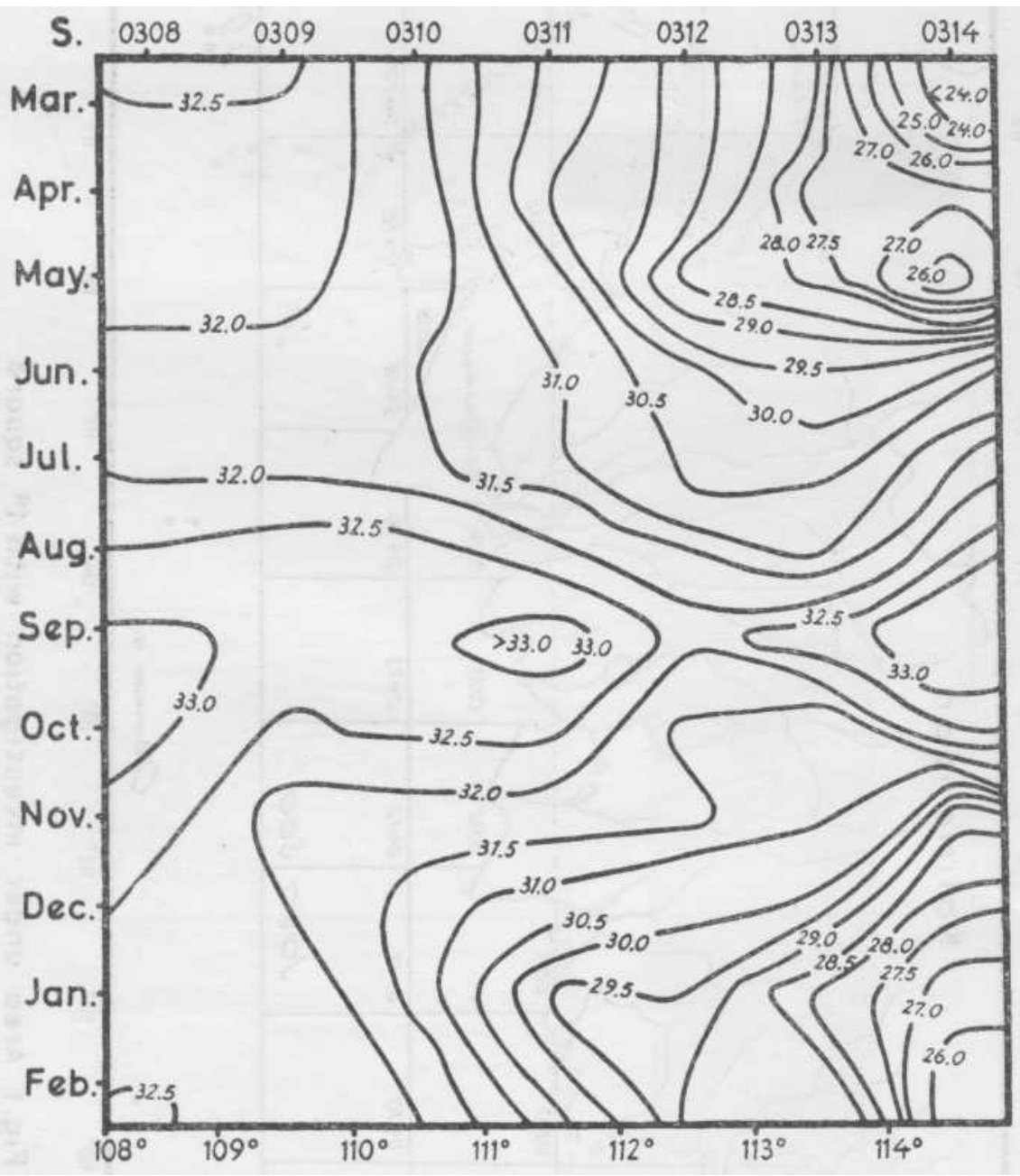

Fig. 2. Isopleths of surface salinity along the south coast of Kalimantan 


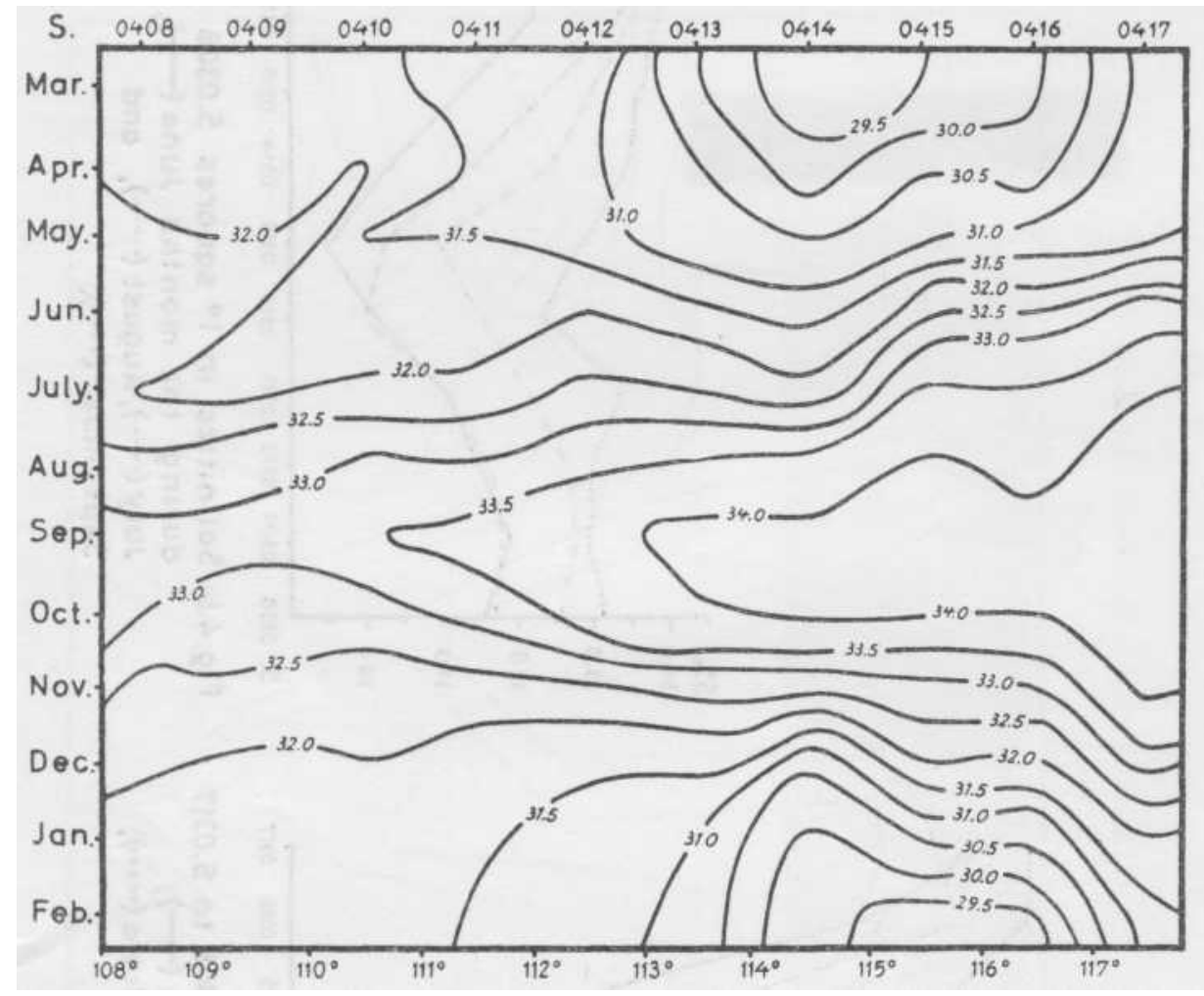

Fig. 3. Isopleths of surface salinity along the south coast of Kalimantan 

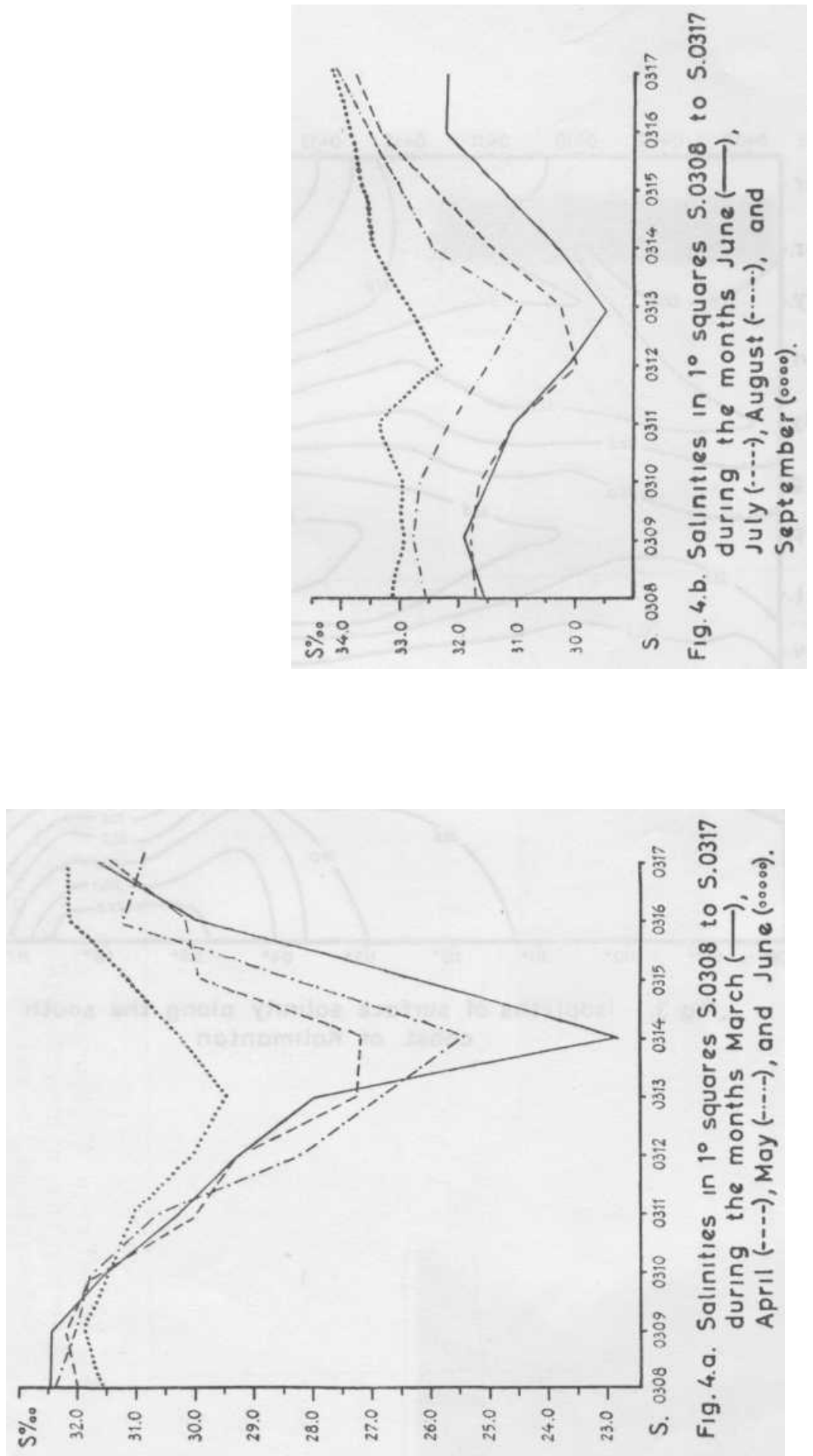

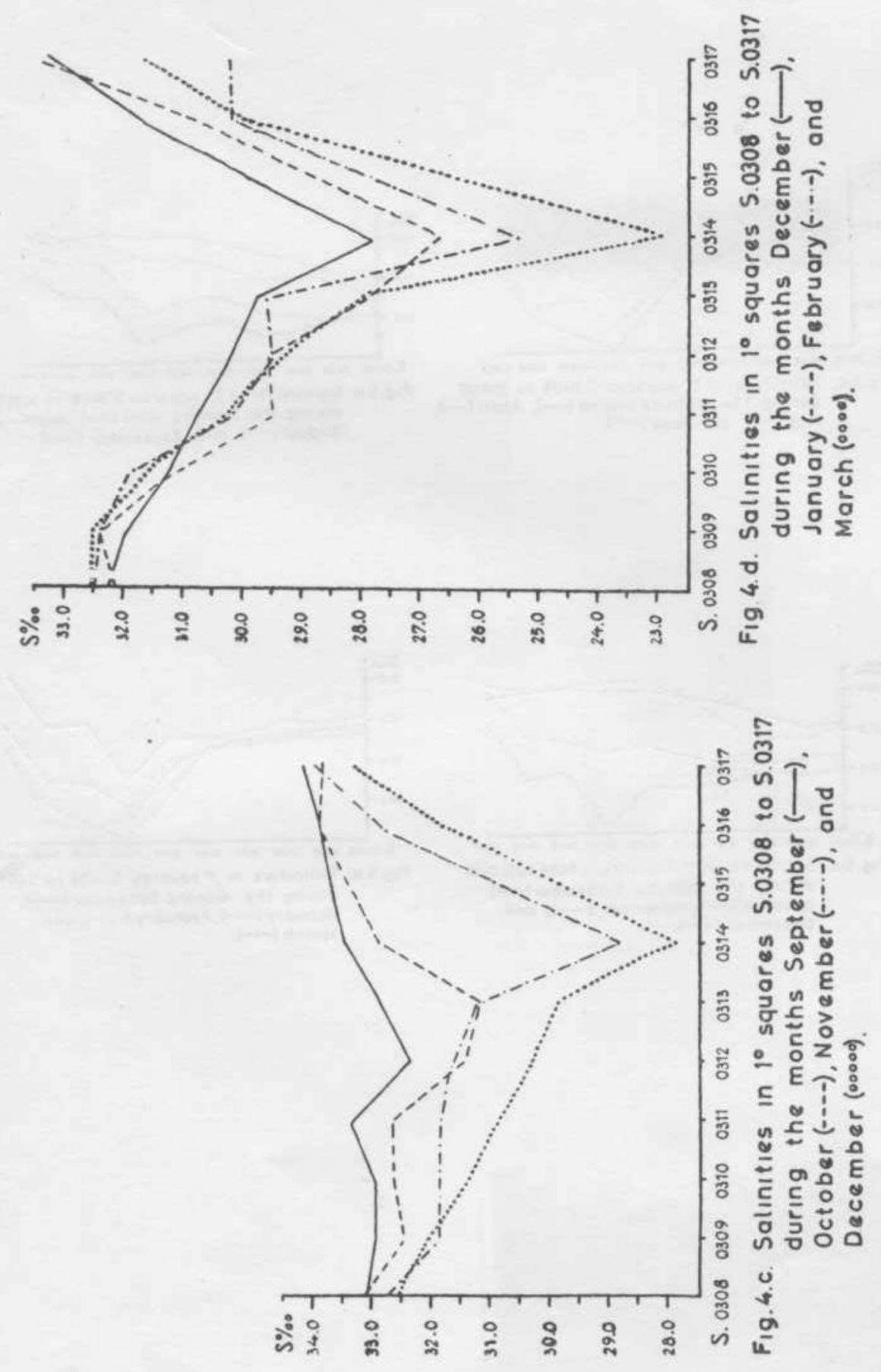

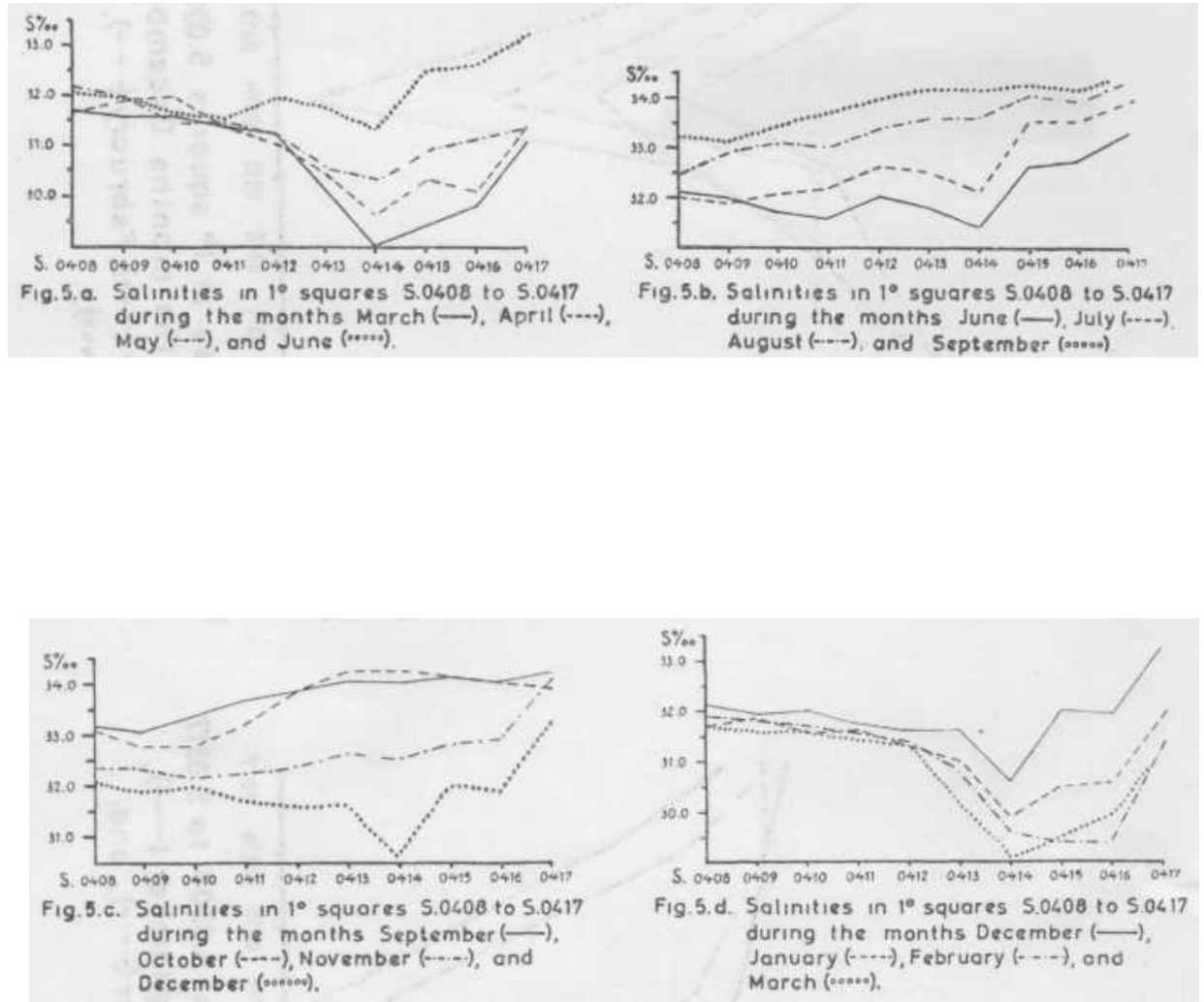

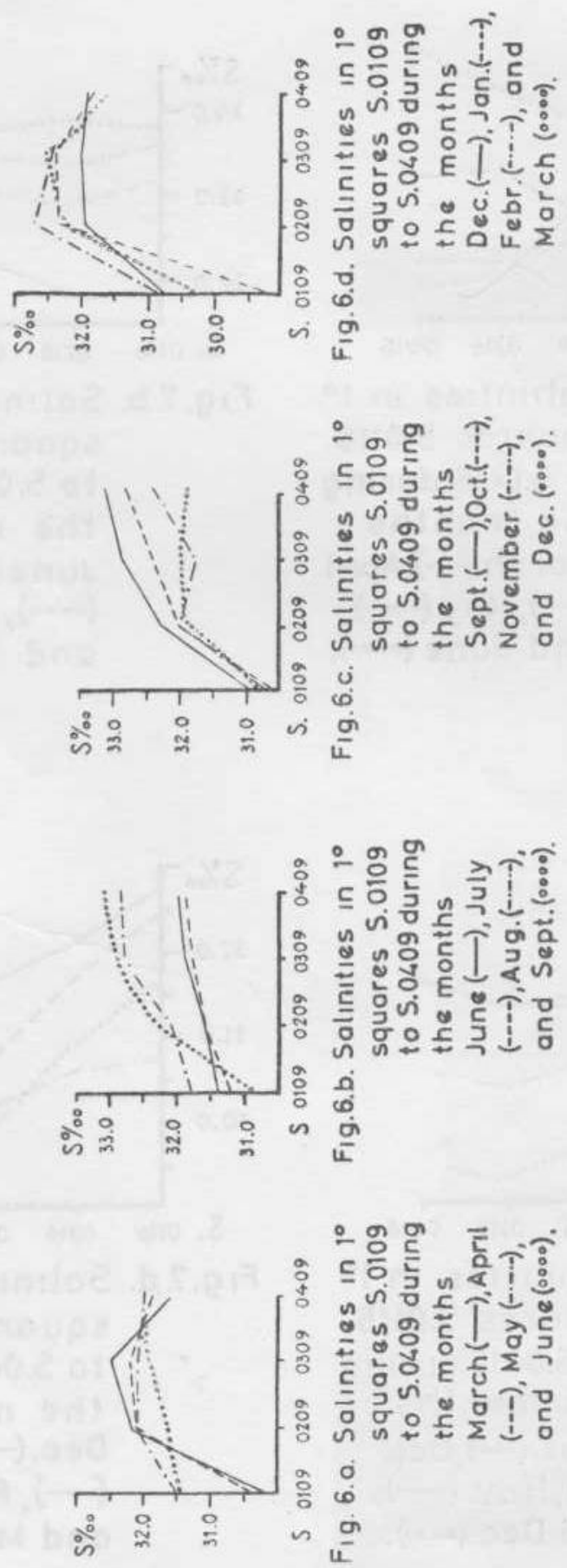


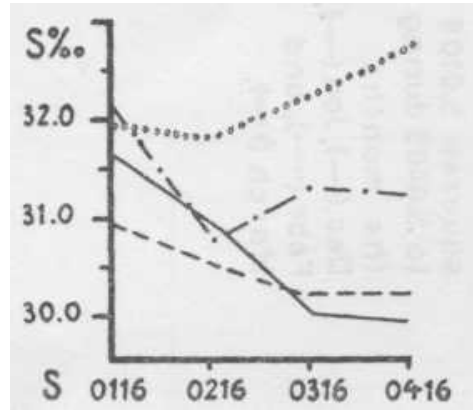

Fig.7.a. Salinities in $1^{\circ}$ squares $\mathrm{S} .0116$ to 5.0416 during the months March (-),April $(-\cdots)$, May $(-\cdots)$, and June (0000).

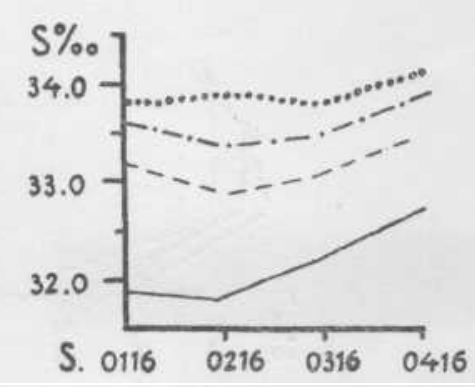

Fig. 7.b. Salinities in $1^{\circ}$ squares 5.0116 to 5.0416 during the months June $(-$, July $(---)$, Aug. (---)), and Sept.(0000).

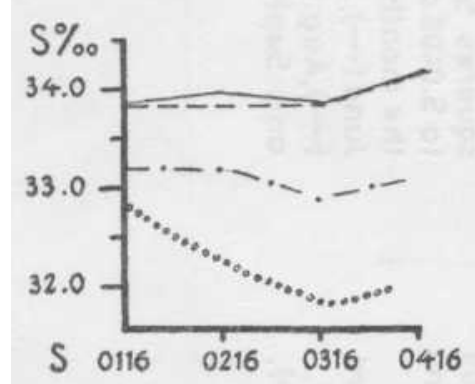

Fig.7.c. Salinities in $1^{\circ}$ squares 5.0116 to 5.0416 during the months Sept.(-), Oct. $(-\rightarrow)$, Nov. $(-\cdots)$, and Dec (0000).

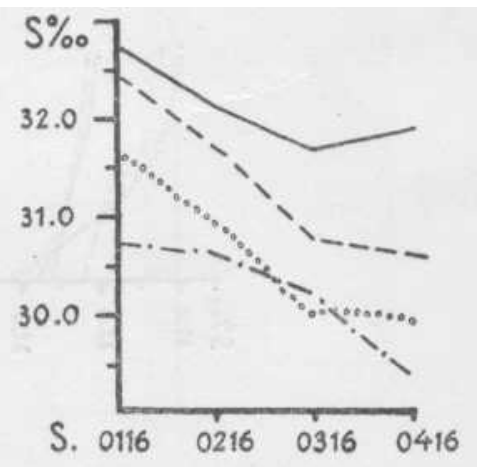

Fig.7.d. Salinities in $1^{\circ}$ squares 5.0116 to 5.0416 during the months Dec. $(-)$, Jan. $(--)$, Febr. $(-\cdots)$, and March (000\%). 


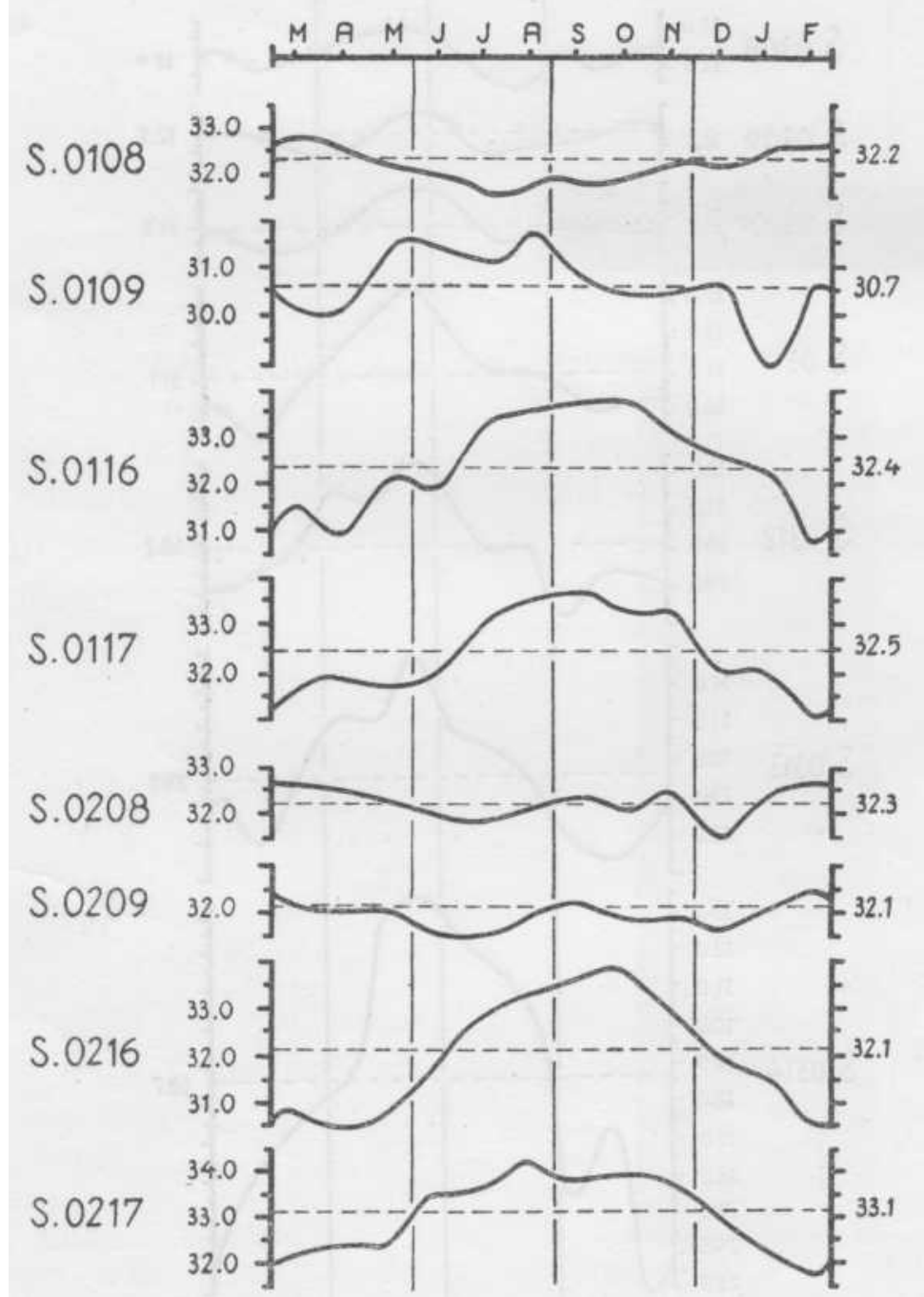

Fig.8. The annual variation and the annual mean of salinity for every $1^{\circ}$ square 


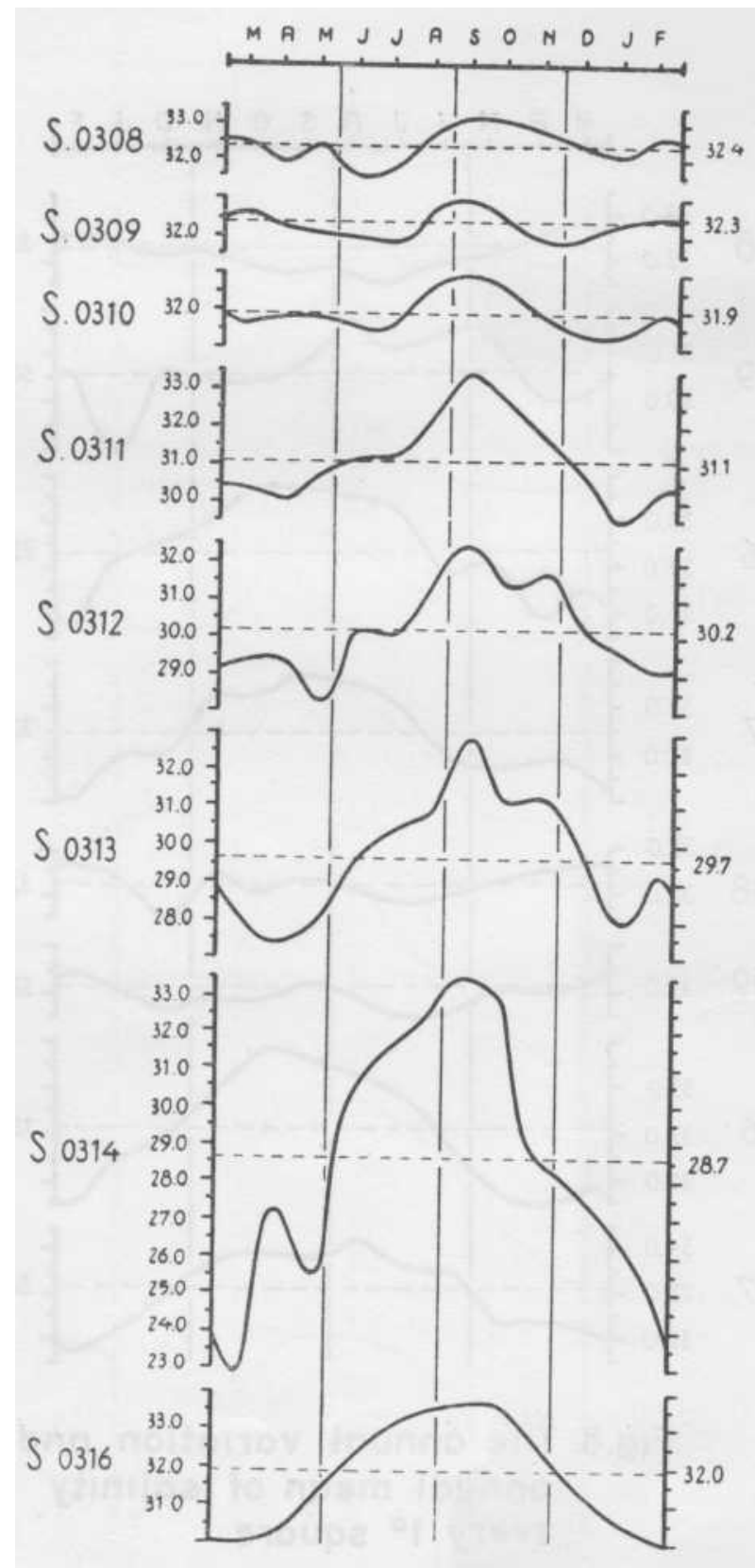

Fig 9. The annual variation and the annual mean of salinity for every $1^{\circ}$ square 


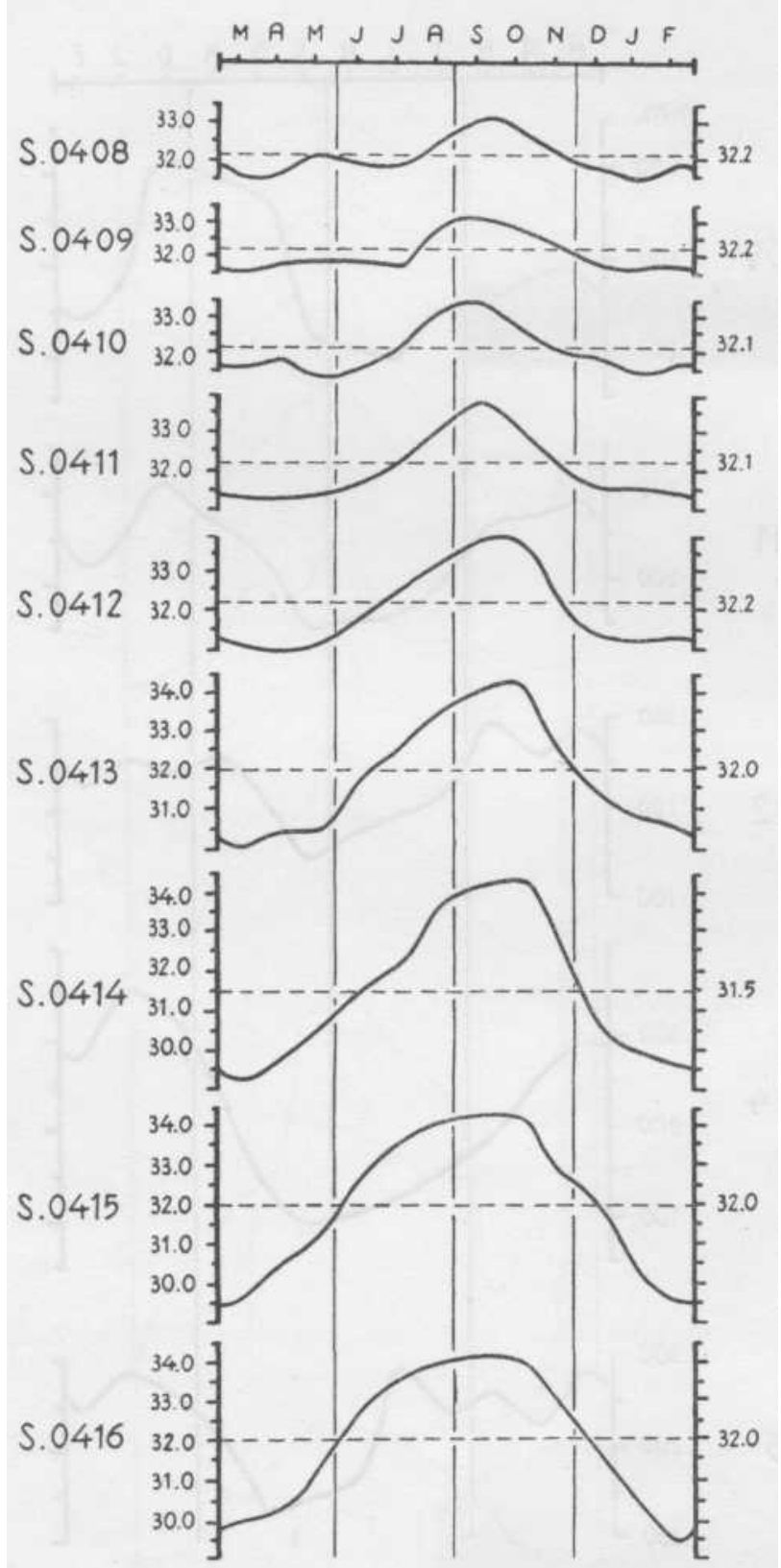

Fig.10. The annual variation and the annual mean of salinity for every $1^{\circ}$ square 


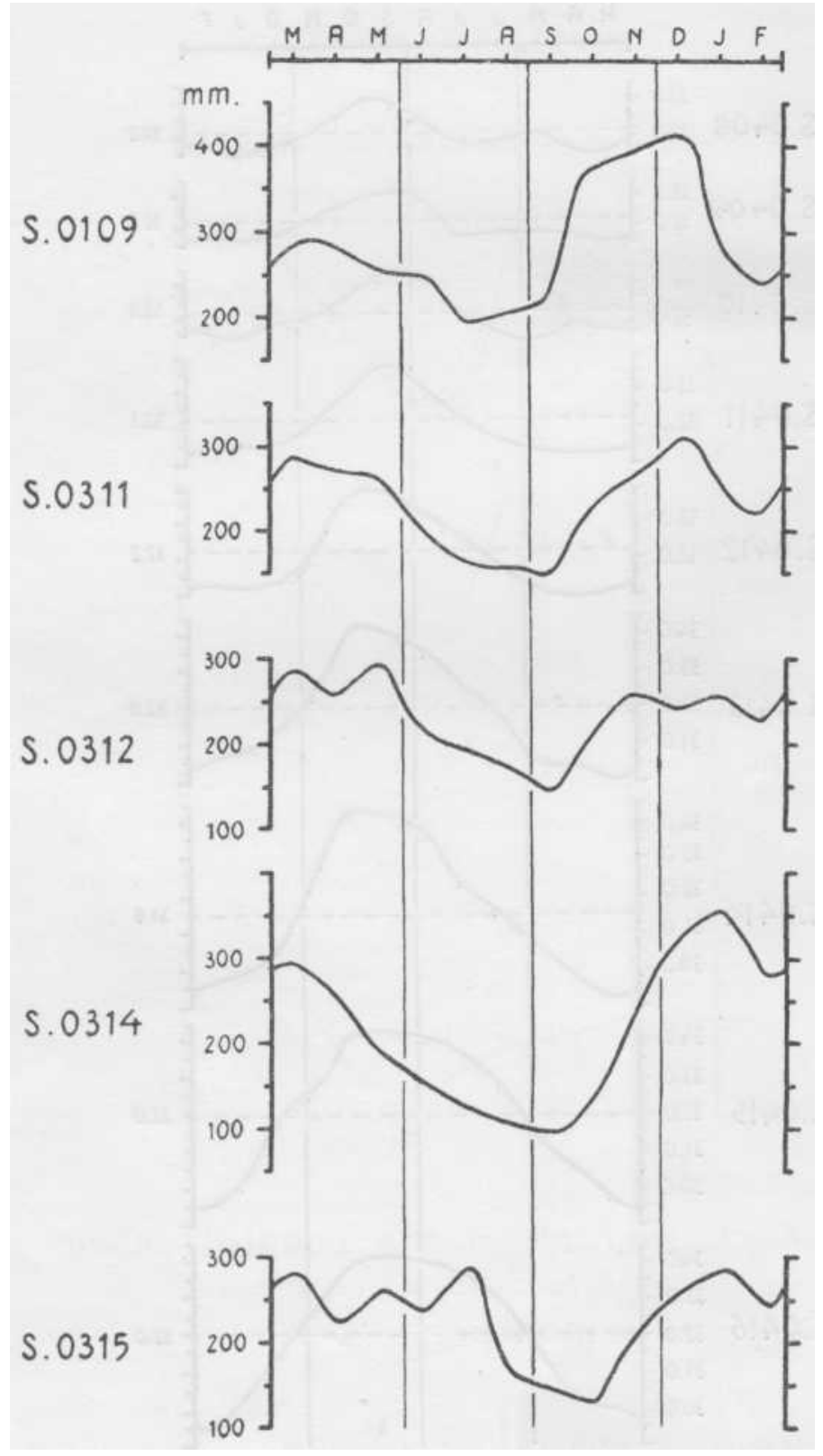

Fig.11. Rainfall in the coastal region of the Southern part of Kalimantan 


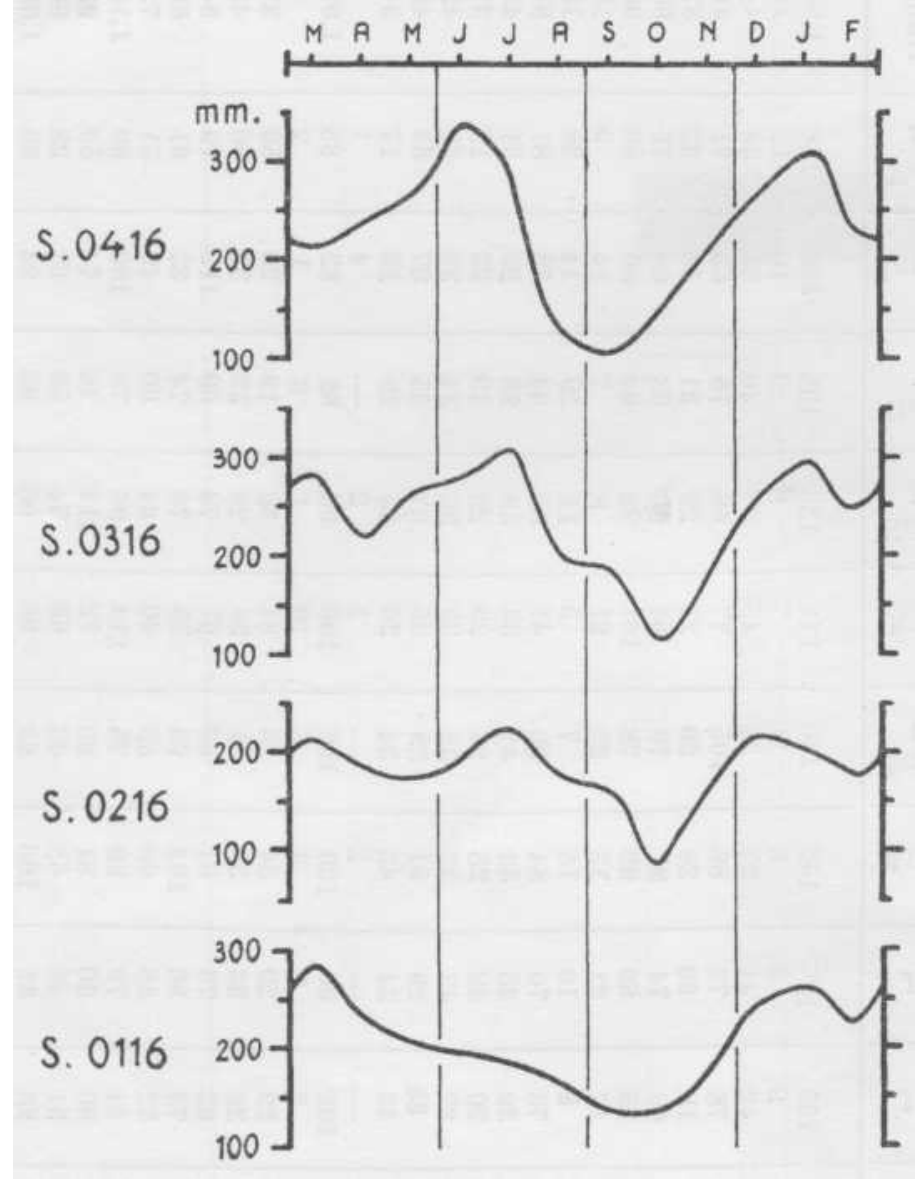

Fig.12. Rainfall in the coastal region of the Southern part of Kalimantan 


\begin{tabular}{|c|c|c|}
\hline & 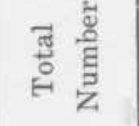 & 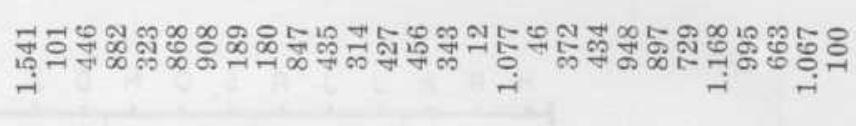 \\
\hline & $\begin{array}{c}\text { K.xв } \\
- \text { n.xqวa } \\
\end{array}$ & 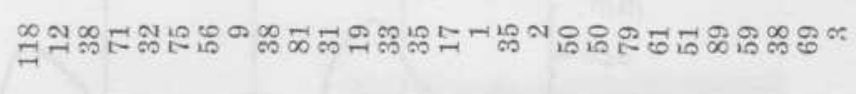 \\
\hline & К.xвnuв & 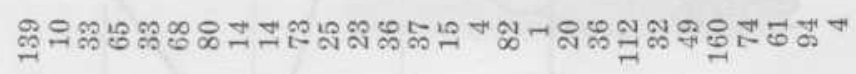 \\
\hline $\begin{array}{l}\text { S } \\
\text { 풀 }\end{array}$ & $\begin{array}{c}\text { teq } \\
\text {-twəวad }\end{array}$ & 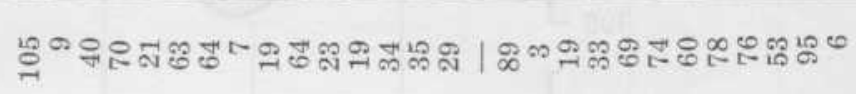 \\
\hline 蒫 & $\begin{array}{c}\text { xәq } \\
- \text { was. }\end{array}$ & 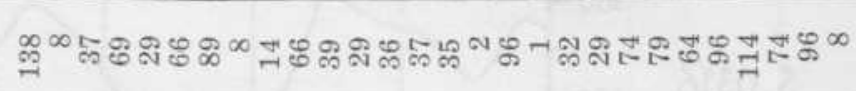 \\
\hline 产 & хаqорэо & 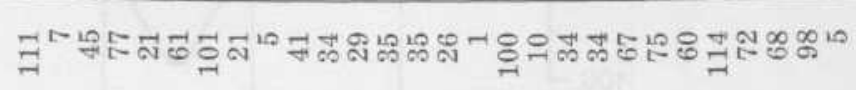 \\
\hline $\begin{array}{l}\vec{Z} \\
\text { क } \\
a\end{array}$ & $\begin{array}{c}x ә q \\
\text {-uəzdəs }\end{array}$ & 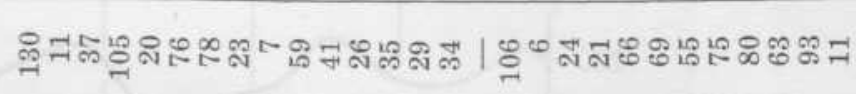 \\
\hline$\frac{02}{0}$ & 7sn.̊กท & ㅁำ \\
\hline $\begin{array}{l}\text { 总 } \\
\text { 兑 }\end{array}$ & $\kappa \mathrm{I}_{\mathrm{f}}$ & 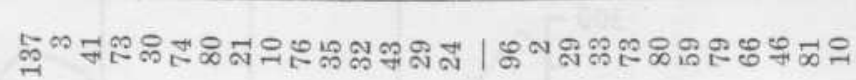 \\
\hline 풀 & ounf & 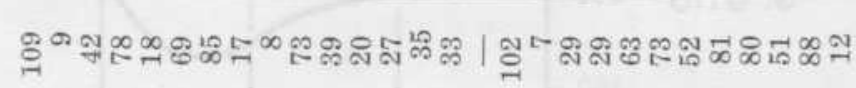 \\
\hline$-i$ & $\kappa \mathbb{E}_{\mathrm{W}}$ & ్ㅟㅇㅠదี \\
\hline$F$ & It.rdV & 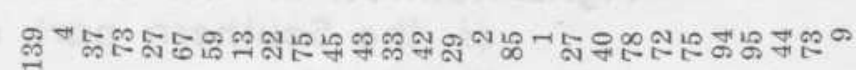 \\
\hline & чэлек & 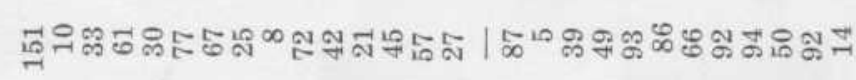 \\
\hline 总 & $\begin{array}{l}\text { हूँ } \\
\text { है } \\
\text { है } \\
\text { है } \\
\text { 乙 }\end{array}$ & 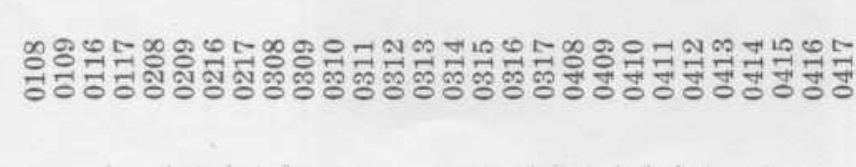 \\
\hline
\end{tabular}




\begin{tabular}{|c|c|c|}
\hline & 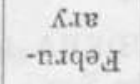 & 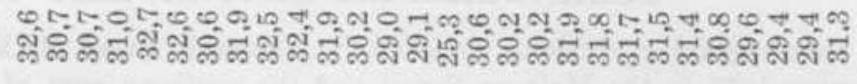 \\
\hline & Axznuв & 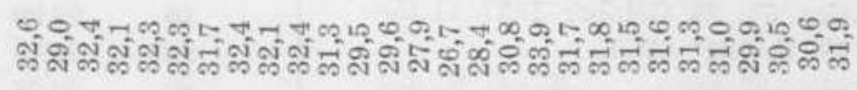 \\
\hline & 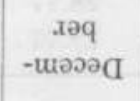 & 눈 \\
\hline & $\begin{array}{c}x ә q \\
- \text {-นวนоN }\end{array}$ & 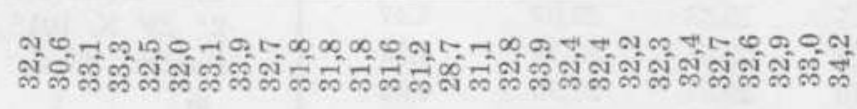 \\
\hline & xәчочวо & 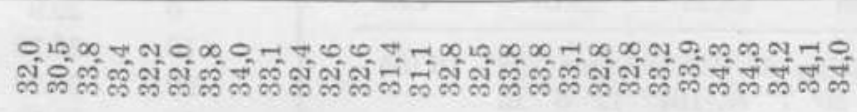 \\
\hline & $\begin{array}{c}x ә q \\
- \text { urądas }\end{array}$ & 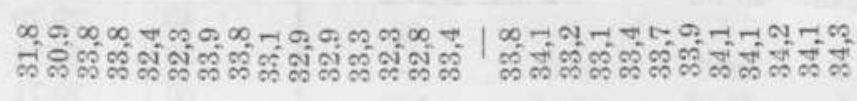 \\
\hline & $7 \operatorname{sn} 8 \mathrm{n}_{\mathrm{V}}$ & 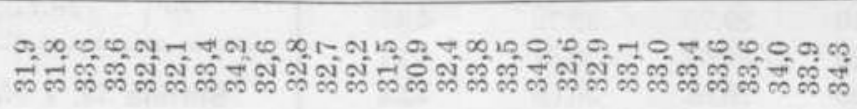 \\
\hline & $\kappa_{\mathrm{I}} \mathrm{n}_{\mathrm{I}}$ & 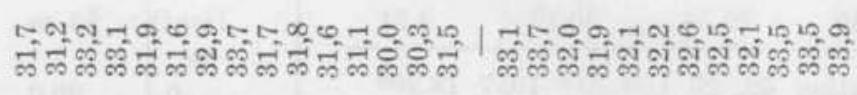 \\
\hline & oun $\rho$ & 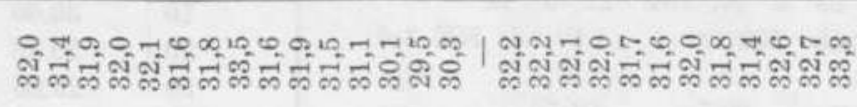 \\
\hline & ¿खW & 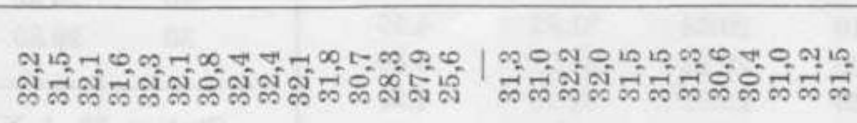 \\
\hline & I! $t \boldsymbol{d} \mathrm{V}$ & 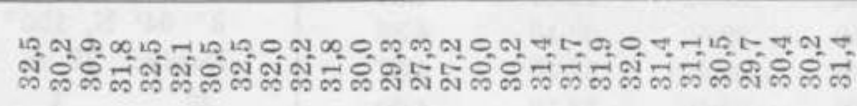 \\
\hline$=$ & पุग्र & 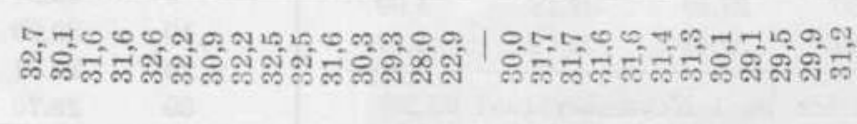 \\
\hline 芯 & 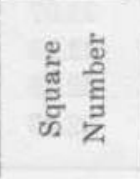 & 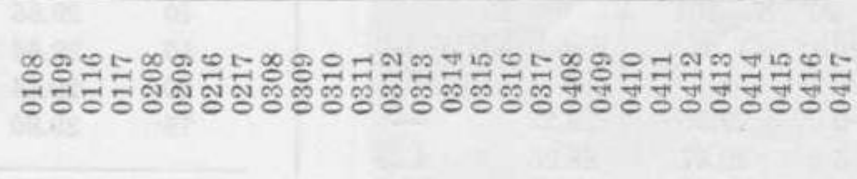 \\
\hline
\end{tabular}

